\title{
LABORATORY SIMULATIONS OF THE TRANSFORMATION OF EMMER WHEAT AS A RESULT OF HEATING
}

\author{
F. Braadbaart ${ }^{1,2^{*}}$, J. van der Horst ${ }^{1}$, J. J. Boon ${ }^{1}$ and \\ P. F. van Bergen ${ }^{2 * *}$ \\ ${ }^{1}$ FOM Institute for Atomic and Molecular Physics, Kruislaan 407, 1098 SJ Amsterdam, \\ The Netherlands \\ ${ }^{2}$ Department of Earth Sciences-Geochemistry, Faculty of Geosciences, Utrecht University, \\ P.O. Box 80021, 3058 TA Utrecht, The Netherlands
}

(Received December 20, 2003; in revised form March 30, 2004)

\begin{abstract}
Whole grains of emmer wheat were heated in a pre-heated tube oven at temperatures ranging from $130-700^{\circ} \mathrm{C}$ under controlled anoxic conditions for maximum $280 \mathrm{~min}$. For each temperature a separate experiment was carried out. Physical properties including mass loss, thermal lag, external and internal morphology and the vitrinite reflectance, $\mathrm{C}$ and $\mathrm{N}$ content, and DTMS under $\mathrm{CI}\left(\mathrm{NH}_{3}\right)$ and EI conditions were used to monitor changes as a function of the temperature. The results show remaining starch and protein rich material up to $250^{\circ} \mathrm{C}$. From $310-400^{\circ} \mathrm{C}$ a secondary, thermally stable, product is formed and at higher temperatures a strongly carbon enriched tertiary product.
\end{abstract}

Keywords: carbonization, DTMS, emmer wheat, heat treatment

\section{Introduction}

Carbonized remains of wood, fruits and seeds are often found in the archaeological record [1]. The carbonization process can be considered as the first of a series of formation processes that may have affected these remains, prior to the description by the archaeologists [2,3]. The effects of the various formation processes on the carbonized material will depend on its physical and chemical properties. To understand these properties modern fruits and seeds of three different species of plants were selected. Samples of these fruits and seeds were heated under controlled anoxic conditions at atmospheric pressure to simulate carbonization, a thermochemical degradation process [4]. The three species selected are the dicotyledon peas (Pisum sativum L.) and linseed (Linum usitatissimum L.), and the monocotyledon emmer

* Author for correspondence: E-mail: brabra@wxs.nl

** Current address: Flow Assurance, Shell Global Solutions International B. V., P.O. Box 38000, 1030 BN Amsterdam, The Netherlands 
wheat (Triticum dicoccum Schübl), a monocotyledon. The term carbonization, which is usually used in a rather general way, is not further used in this study and replaced by heat treatment plus the temperature at which the heating took place.

The current study assesses the changes as a function of temperature, of the physical properties, the bulk chemical composition and the molecular composition of grains of emmer wheat. A grain of wheat is a single seeded fruit, composed of an endosperm and an embryo enclosed by a multi-layered pericarp or fruit coat. The presence of this pericarp will affect the way that the morphology changes as a result of heating [5]. The morphology of wheat grains is species dependent and even on a variety level differences occur $[6,7]$. Moreover grains in each variety may appear translucent or opaque, so-called vitreous and mealy, respectively [7]. The morphological differences that exist between species allow for an easy distinction between for example bread wheat (Triticum aestivum L.) and emmer wheat. However, after heat treatment the grains of both species become more similar [8].

An appropriate selection of a variety of emmer wheat was needed considering the heterogeneous character of wheat grain varieties. For this purpose heating experiments at a temperature of $270^{\circ} \mathrm{C}$ were carried out on seven varieties of emmer wheat, two varieties of bread wheat and one variety of durum wheat (Triticum durum Desf.) [5]. The results showed a wide range of physical and bulk chemical differences between the grains of the ten varieties. Most conspicuous were the variations in the mechanical properties of the pericarp and the varying content of proteins. The molecular composition as determined by DTMS however, showed no differences between the untreated grains nor between the heated residues of the ten varieties [5]. Based on these results the variety of emmer wheat AR, as one of the first species of wheat used in agriculture, was selected for the experiments. Experiments were carried out to investigate the changes as a function of the temperature, of mass loss, morphology, bulk chemical properties, molecular composition and vitrinite reflectance.

\section{Material and methods}

\section{Samples}

Emmer wheat was grown at ARCHEON, Alphen aan de Rijn, The Netherlands and will be referred to as AR [5]. The wheat was harvested in the summer of 2002. For the experiments the chaff was removed from the grains. No selection took place between mealy and vitreous grains and the sample contained the grains as naturally present. Meneba Meel B.V., Rotterdam, The Netherlands kindly supplied reference samples (technical grade) of wheat starch and wheat protein isolate.

\section{Heat treatment}

Wheat grains were heated in a preheated Carbolite tube oven (model MTF 12/38/250) whereby the rate of heating was limited by setting a ramp rate of $2^{\circ} \mathrm{C} \mathrm{min}{ }^{-1}$. An open pyrex vessel was inserted in a $30 \mathrm{~cm}$ long pyrex tube $(\varnothing 2.3 \mathrm{~cm})$ at $18 \mathrm{~cm}$ from the inlet. 
The experiments were carried out under a constant flow $\left(150 \mathrm{~mL} \mathrm{~min}^{-1}\right)$ of $\mathrm{N}_{2}$ at atmospheric pressure. In initial experiments 40 grains of AR were placed in the pyrex vessel and heated in the preheated oven at temperatures $\left(T_{\text {oven }}\right)$ of $220,250,270,290,310$, 340,440 and $600^{\circ} \mathrm{C}$ as a function of time for 7.5 up to $280 \mathrm{~min}$ to determine the optimal heating time. Based on these initial results grains of AR were heated for $120 \mathrm{~min}$ at one of the following temperatures: 130, 160, 190, 220, 235, 250, 270, 290, 310, 340, 370, $400,440,500,600$ and $700^{\circ} \mathrm{C}$. Forty grains were used up to an $T_{\text {oven }}=370^{\circ} \mathrm{C}$, at higher temperatures 60 grains were used. The pyrex vessel with the grains of AR was weighed before and after heating, in order to determine the percentage mass loss. Gases and volatiles were vented and not further investigated.

The variation, as a function of the time, between the internal temperature of the grains and external gas temperature was measured with one grain of AR in the pyrex vessel. A hole $(\varnothing 0.3 \mathrm{~mm})$ was drilled in the grain and a ' $\mathrm{K}$ ' type thermocouple was inserted in the centre of it. A similar type of thermocouple placed just beside the grain monitored the temperature of the carrier gas. The exposed wires were insulated with glass fibre. The thermocouples were connected to a two-channel writer (Kipp en Zonen, model BD41) and the temperatures were recorded continuously vs. time. The thermocouples were calibrated with a pyrometer.

\section{Microscopy}

Visual changes in the external gross morphology of whole untreated wheat and the residues of the grains of AR as a function of the oven temperature were studied using a Zeiss incident light stereomicroscope. Scanning electron microscopy (SEM) was used to study the internal changes on fresh cross sections of specimens, heated up to $270^{\circ} \mathrm{C}$, cut in half using a razor blade. At higher temperatures the vitrinite reflection was measured and the internal morphology was examined on polished resin-embedded specimens using a Zeiss Axioskop reflected light microscope [9].

\section{Elemental analyses}

Seven whole untreated grains of AR or residues thereof were used after grinding and mixing. C and N analyses were executed on a NA 1500 series 2 NCS analyser from Fisons Instruments. The temperature in the combustion reactor was maintained at $1020^{\circ} \mathrm{C}$. The combustion products were separated on a Porapak QS column with a length of $2 \mathrm{~m}$. All values stated are based on at least two measurements corrected for $\mathrm{H}_{2} \mathrm{O}$ and ash content (daf: dry and ash free). $\mathrm{H}_{2} \mathrm{O}$ and ash content were determined on a Thermogravimetric Analyser TGA 2950 Hi-Res. The carrier gas was air and the heating rate was set at $25^{\circ} \mathrm{C} \mathrm{min}^{-1}$, water content was determined at $105^{\circ} \mathrm{C}$ and ash content at $950^{\circ} \mathrm{C}$.

\section{Vitrinite reflectance measurements}

The residues of whole grains of $\mathrm{AR}$, heated for $120 \mathrm{~min}$ at oven temperatures ranging from 270 to $700^{\circ} \mathrm{C}$ were used. For each oven temperature three specimens were em- 
bedded in resin blocks and polished. Maximum vitrinite reflectance measurements $\left(\% R_{\max }\right)$ were carried out under oil immersion at a wavelength of $546 \mathrm{~mm}$ using a Leitz MPV II microscope system. Thirty reflectance measurements were made on each specimen and at least two residues heated at the same temperature were used to calculate the mean reflectance. Preparation of polished blocks and reflectance measurements were carried out according to standard methods defined in ISO 7404, part 2 [9] and ISO 7404, part 5 [10].

\section{Direct temperature-resolved mass spectrometry (DTMS)}

The mass spectrometer used was a JEOL SX-102A double focusing mass spectrometer (B/E), using a direct insertion probe equipped with a $\mathrm{Pt} / \mathrm{Rh}(9 / 1)$ filament for analysis under both chemical ionization (CI) and electron ionization (EI) conditions. The sample consisting of the powdered mixture of seven whole grains or residues thereof was deposited on the filament of the filament and inserted directly into the ion source of the mass spectrometer. Previous measurements on residues of peas showed that the sampling and experimental variance was very small [11]. Therefore only single measurements were carried out. For CI, ions were generated under positive ammonia chemical ionization conditions. The accelerating voltage was $2.2 \mathrm{kV}$, the scan range was $m / z$ 60-1000 and the mass resolution was set at 1000. Under EI conditions ions were generated by low voltage electron ionization $(16 \mathrm{eV})$ in an ionization chamber kept at $180^{\circ} \mathrm{C}$ and accelerated to $10 \mathrm{kV}$. The scan range was $\mathrm{m} / z$ 20-1000 with $1 \mathrm{~s}$ cycle time and mass resolution of 1000. For both methods data were acquired using a JEOL MP-7000 data system. Data acquisition and processing was performed on-line. The results of the DTMS experiments were subjected to multivariate analysis. In this study Principal Components Analyses (PCA), in combination with graphical rotation [12], was performed on the results of the DTMS experiments, using the FOMpyroMap multivariate program and the ChemomeTricks program for the calculations [13].

\section{Results}

\section{Mass loss and optimization of the heating time}

The mass loss of the grains of wheat was determined as a function of time in min at the various oven temperatures $\left(T_{\text {oven }}\right)$. The experimental conditions did not allow continuous measurement of the mass loss during the entire time range of $280 \mathrm{~min}$. A separate experiment was necessary for each time interval. The results show that for each $T_{\text {oven }}$ the mass loss reaches a constant level after a certain time (Fig. 1). The higher the $T_{\text {oven }}$ the shorter the time to reach the constant level for example it takes ca. $120 \mathrm{~min}$ at $T_{\text {oven }}=250^{\circ} \mathrm{C}$, ca. $20 \mathrm{~min}$ at $T_{\text {oven }}=290^{\circ} \mathrm{C}$, but it only takes $5 \mathrm{~min}$ at $T_{\text {oven }}=600^{\circ} \mathrm{C}$. It was shown in any case for oven temperatures from $250^{\circ} \mathrm{C}$ upwards that the molecular composition remains constant after the total mass loss has become constant [11]. Following these results a heating time of $120 \mathrm{~min}$ for each heating experiment is considered sufficient. 


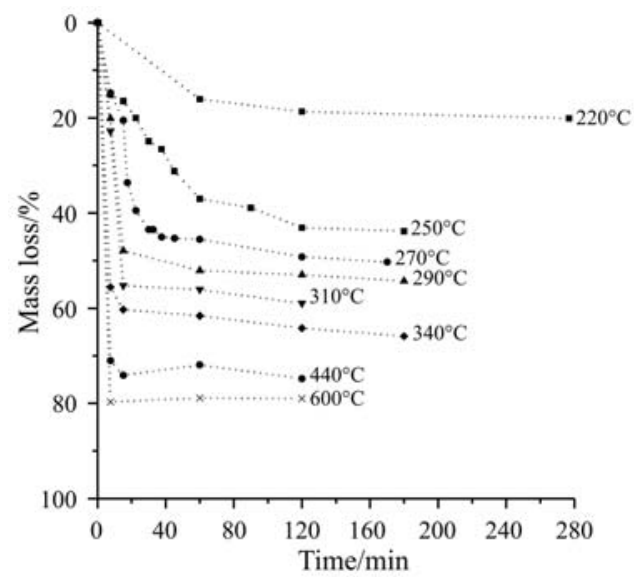

Fig. 1 Mass loss (\%) of heated grains of emmer wheat (var. AR) as a function of the heating time in min. The oven temperature is indicated in the figure in ${ }^{\circ} \mathrm{C}$

Heating experiments were carried out at oven temperatures in the range of 130 to $700^{\circ} \mathrm{C}$ for $120 \mathrm{~min}$. A strong rate of mass loss was observed in the range of $T_{\text {oven }}=220$ to $250^{\circ} \mathrm{C}$, after which the rate of mass loss slowly decreased with temperature (Fig. 2). The total mass loss does not become constant. For comparative reasons the mass loss of microcrystalline cellulose heated for $2.5 \mathrm{~h}$ under almost identical conditions [14] is shown. Cellulose shows a higher mass loss from $T_{\text {oven }}>270^{\circ} \mathrm{C}$ and is almost completely converted to volatile matter at $400^{\circ} \mathrm{C}$.

One grain of AR was heated in a pre-heated oven to determine the thermal regime inside the grains [15]. The temperature, as a function of the time, inside and outside the grain was measured using thermocouples. The results show that the external temperature $T_{\text {ext }}\left({ }^{\circ} \mathrm{C}\right)$ in the first stage was greater than the internal temperature $T_{\text {int }}\left({ }^{\circ} \mathrm{C}\right)$

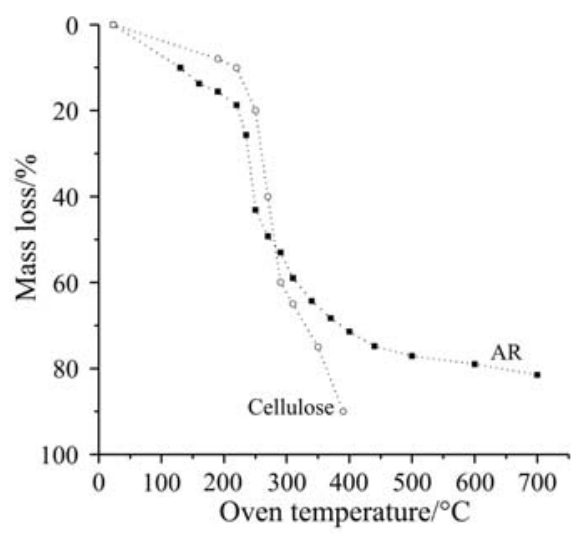

Fig. 2 Mass loss (\%) of grains of emmer wheat (var. AR) heated for $120 \mathrm{~min}$ as a function of the oven temperature in ${ }^{\circ} \mathrm{C}$. Microcrystalline cellulose is heated for $2.5 \mathrm{~h}$ after Pastorova et al., 1993 [14] 
of the grains. Thus a positive thermal lag (i.e. $T_{\mathrm{ext}}-T_{\mathrm{int}}>0$ ) was observed. However after a certain time period $T_{\text {ext }}$ becomes equal to $T_{\text {int }}$. This period depends on the temperature set for the experiment. At $T_{\text {oven }}=250^{\circ} \mathrm{C} T_{\text {int }}$ becomes equal to $T_{\text {ext }}$ after $10 \mathrm{~min}$. At higher oven temperature this time period decreases; at $T_{\text {oven }}=310^{\circ} \mathrm{C} 7 \mathrm{~min}$ and at $T_{\text {oven }}=400^{\circ} \mathrm{C} 3.5 \mathrm{~min}$. From $T_{\text {oven }}=310^{\circ} \mathrm{C}$ upwards the $T_{\text {ext }}=T_{\text {int }}$ stage is followed by a negative thermal lag $\left(T_{\mathrm{ext}}-T_{\mathrm{int}}<0\right)$ for a maximum of two min. Subsequently the negative lag becomes again a positive lag at higher temperatures. At all oven temperatures $T_{\text {ext }}$ becomes constant upon reaching the predefined oven temperature of each experiment. Some minutes later $T_{\text {int }}$ also becomes constant, but at about $2^{\circ} \mathrm{C}$ lower than $T_{\text {ext. }}$. The positive thermal lag is a signature of an endothermic or heat demanding reaction, which is present over the entire range of oven temperatures. From $T_{\text {oven }}=310^{\circ} \mathrm{C}$ upwards the positive thermal lag is followed by a negative thermal lag, which signifies an exothermic reaction [16]. The most important changes are summarized in Scheme 1.

\section{Morphology}

The morphology and anatomy of wheat grains in general has been described in an earlier paper [5] and the description of the morphology of grains of AR is therefore confined to its particulars. The length of the grains varies between $5.8-8.4 \mathrm{~mm}$ and the width from 1.7-3.2 mm. The study by light microscopy shows an outside colour of greyish yellow. Untreated grains show from the outside inwards the various cell layers of the pericarp, followed by the round cells of the aleurone layer, the outermost layer of the endosperm $[17,18]$. The latter is followed by the endosperm without a distinct cell structure, probably as a result of the preparation method. The endosperm shows a densely packed structure with starch granules embedded in a proteinaceous matrix, followed by a less densely packed structure and finally in the middle of the grain the endosperm structure can be described as loosely packed [18].

The external changes as a result of heating of the grains of AR as determined by light microscope show a change in the outside colour from greyish yellow through brown to black at $T_{\text {oven }}=290^{\circ} \mathrm{C}$ (Table 2). The formation of grains with an open crease or solid protrusions on the grains as a result of heating has been described in an earlier paper [5]. Up to $T_{\text {oven }}=250^{\circ} \mathrm{C}$ no grains are observed with a protrusion. At $T_{\text {oven }}=270^{\circ} \mathrm{C} 64 \%$ of the grains have a protrusion. This increased to $88 \%$ at $290^{\circ} \mathrm{C}$ (Table 2). This percentage does not change until $T_{\text {oven }}=370^{\circ} \mathrm{C}$; subsequently it decreases to $21 \%$ at $T_{\text {oven }}=700^{\circ} \mathrm{C}$ (Scheme 1). Upon heating of the grains the size and/or shape change, resulting in swollen grains at $250^{\circ} \mathrm{C}$. Subsequently the size decreases and the grains get rounder. The details of these dimensional changes as a result of heating will be discussed in a separate paper. At $T_{\text {oven }}=340^{\circ} \mathrm{C}$ the pericarp shows vesicles and this feature is present until $T_{\text {oven }}=400^{\circ} \mathrm{C}$. The colour of the endosperm changes from white through brown to black at $T_{\text {oven }}=270^{\circ} \mathrm{C}$ (Table 2). The internal structure of the residues of grains heated at $T_{\text {oven }}=190$ and $235^{\circ} \mathrm{C}$ show no change compared with the structure of the untreated grain. The starch granules in the matrix material remain visible and have not changed in size. Towards the middle of the grain 
the matrix becomes more loosely packed. The residue heated at $270^{\circ} \mathrm{C}$ reveals a drastic change in the internal structure showing a still intact pericarp and aleurone layer, but the endosperm consists now of cavities in a matrix of grey solid material, which is chemically converted endosperm material. This general feature does not change anymore at the higher temperatures. The changes of the morphology with temperature are shown in Scheme 1.

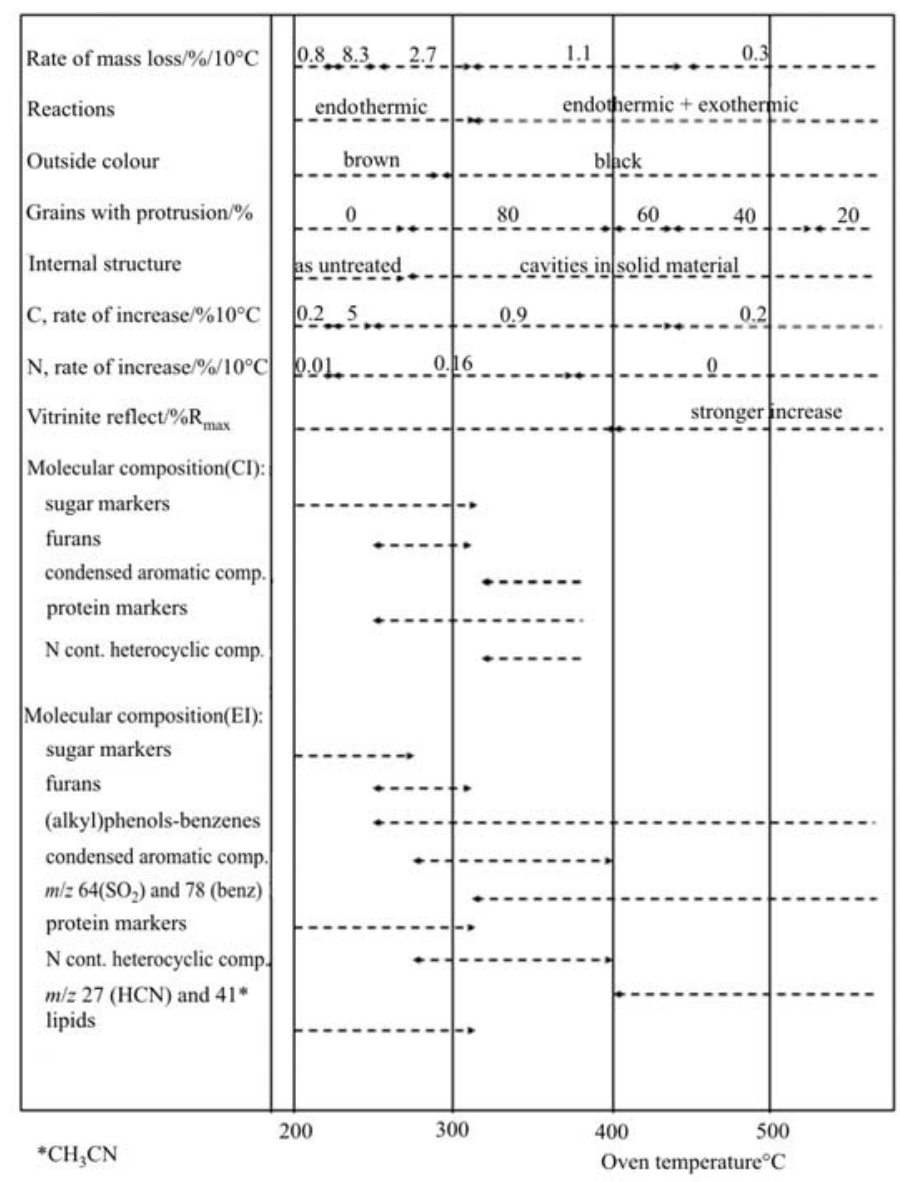

Scheme 1 Classification of the changes of the physical properties, the bulk chemical analyses and the chemical composition of heated grains of emmer wheat (var. AR) as a function of the oven temperature in ${ }^{\circ} \mathrm{C}$. Heating time $120 \mathrm{~min}$

\section{Elemental analyses}

The elemental analyses of the untreated grains of AR show a $\mathrm{C}$ content of 46.3 mass $\%$, daf and an $\mathrm{N}$ content of 2.1 mass $\%$, daf (Fig. 3). The results of the car- 
bon (solid line) and nitrogen (dotted line) analyses of heat treated samples reveal a relative increase of the content of both elements as a function of oven temperature (Fig. 3). Starting at $T_{\text {oven }}=220^{\circ} \mathrm{C}$ the $\mathrm{C}$ content increases sharply almost from 50 mass $\%$ (daf) at $220^{\circ} \mathrm{C}$ to $65 \%$ at $T_{\text {oven }}=250^{\circ} \mathrm{C}$. Beyond the latter temperature it increases more slowly to stabilize at almost $90 \%$ (daf) at $T_{\text {oven }}=700^{\circ} \mathrm{C}$. At the same time the $\mathrm{N}$ content increases from 2.7 mass $\%$ (daf) at $T_{\text {oven }}=220^{\circ} \mathrm{C}$ to about $5 \%$ (daf) at $T_{\text {oven }}=370^{\circ} \mathrm{C}$ and afterwards remains more or less constant until the highest oven temperature (Scheme 1).

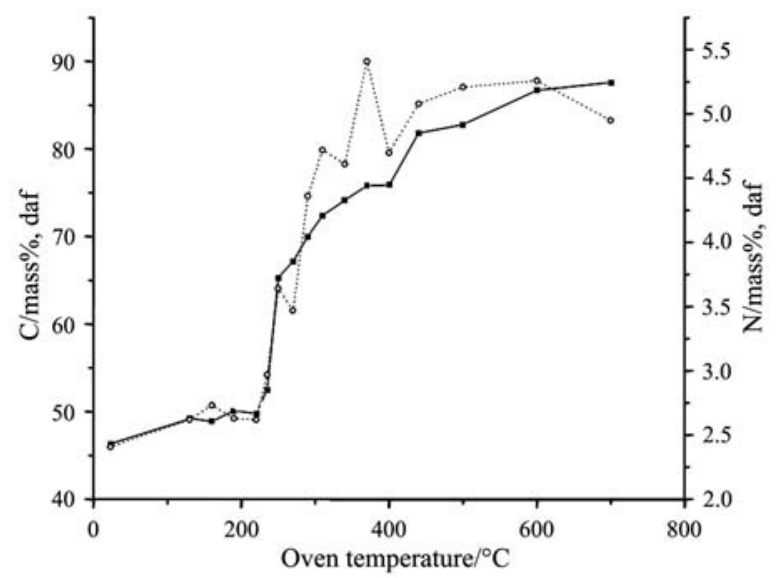

Fig. 3 The results of the bulk elemental analyses of untreated and heated grains of emmer wheat (var. AR) as a function of the oven temperature in ${ }^{\circ} \mathrm{C}$. Heating time 120 min. - $-\mathrm{C}$ content in mass $\%$, daf and $\mathrm{O}-\mathrm{N}$ content in $\operatorname{mass} \%$, daf

Molecular composition by DTMS

DTMS-Cl-NH 3

Polysaccharides, protein and lipids are the common constituents of the endosperm of wheat grains; the bulk material of the grains is polysaccharides represented mainly by starch (Table 1). The CI data of the total ion current (TIC) of the sample of un-

Table 1 Chemical composition of wheat ${ }^{*}$

\begin{tabular}{lc}
\hline & Wheat $/$ mass $\%$ \\
\hline Moisture & 13.2 \\
Protein $\left(\mathrm{N}^{*} 6.25\right)$ & 11.7 \\
Lipids & 2.2 \\
Starch & 59.2 \\
Other carbohydrates & 10.1 \\
Crude fibre & 2.0 \\
Minerals & 1.5 \\
\hline
\end{tabular}


treated grains show a very sharp product distribution with the apex $\left(T_{\max }\right)$ at 78 scans. The known polymer characteristics of polysaccharides, in this case starch, are present in the mass spectrum (not shown) [11]. The protein content is calculated as 13.1 mass \% by applying the factor $\mathrm{N}=6.25$ [19] to the mass \% of the $\mathrm{N}$ content (\%). However, no indicative markers of proteins are observed, due to the high relative abundance of polysaccharide pyrolysis products in the CI spectrum [11]. No information was obtained about lipids, as they ionise poorly under these conditions.

Table 2 Colour and morphology changes in grains of emmer wheat (Triticum dicoccum L.) variety $\mathrm{AR}$ heated for $120 \mathrm{~min}$ at the given oven temperature with $\mathrm{N}_{2}$ as carrier gas

\begin{tabular}{|c|c|c|c|c|c|}
\hline $\begin{array}{c}\text { Oven } \\
\text { temp. } /{ }^{\circ} \mathrm{C}\end{array}$ & $\begin{array}{l}\text { Colour } \\
\text { pericarp }\end{array}$ & $\begin{array}{c}\text { Colour } \\
\text { endosperm }\end{array}$ & $\begin{array}{l}\text { Grains } \\
\text { treated/nr }\end{array}$ & $\begin{array}{l}\text { Grains with } \\
\text { protrusion/\% }\end{array}$ & $\begin{array}{l}\text { Colour tarry liquid } \\
\text { in outlet tube }\end{array}$ \\
\hline untreated & greyish yellow & white & - & - & - \\
\hline 130 & light brown & $\begin{array}{l}\text { blackish } \\
\text { white }\end{array}$ & 40 & 0 & clear \\
\hline 160 & grey-brown & light brown & 40 & 0 & clear \\
\hline 190 & brown-grey & brown & 40 & 0 & clear \\
\hline 220 & brown & dark brown & 40 & 0 & clear \\
\hline 235 & dark brown & brown-black & 40 & 0 & clear \\
\hline 250 & brown-black & black-brown & 40 & 0 & light yellow \\
\hline 270 & black-brown & black & 40 & 64 & yellow \\
\hline 290 & black & black & 40 & 88 & yellow \\
\hline 310 & black & black & 40 & 83 & dark yellow \\
\hline 340 & black & black & 40 & 78 & yellow-brown \\
\hline 370 & black & black & 40 & 83 & yellow-brown \\
\hline 400 & black & black & 60 & 58 & brown \\
\hline 440 & black & black & 60 & 40 & brown \\
\hline 500 & black & black & 40 & 42 & brown \\
\hline 600 & black & black & 60 & 24 & brown \\
\hline 700 & black & black & 60 & 21 & brown \\
\hline
\end{tabular}

Measurements under CI conditions were carried out on powdered solid residues of wheat grains to evaluate the impact of heating on their molecular composition at various oven temperatures. The TIC traces of the samples of grains heated at $T_{\text {oven }}=130$ up to $235^{\circ} \mathrm{C}$ show very sharp product distributions with the apices $\left(T_{\max }\right)$ of the profiles remaining constant. From $T_{\text {oven }}=250^{\circ} \mathrm{C}$ the profile broadens at the high temperature side and the apex shifts to higher scans. The shift points to the presence of an increasing amount of more condensed thermally stable material. The chemical changes that accompany these features are expressed in the mass spectra.

The mass spectra of AR samples heated from $T_{\text {oven }}=130$ to $235^{\circ} \mathrm{C}$ (not shown) are virtually identical to that of the untreated sample being dominated by polysaccha- 
rides. The mass spectra of samples heated at $T_{\text {oven }}=250,270$ (Fig. $4 \mathrm{a}$ ) and $290^{\circ} \mathrm{C}$ have changed in comparison with the mass spectrum of the sample heated at $T_{\text {oven }}=235^{\circ} \mathrm{C}$. In the mass spectrum of the sample heated at $T_{\text {oven }}=310^{\circ} \mathrm{C}$ (Fig. $4 \mathrm{~b}$ ) the relative abundance of mass peaks $(\mathrm{m} / \mathrm{z} 162$ and 180) characteristic for starch has substantially decreased. However, these ions still show a relative intensity of $60 \%$, indicating that structurally intact anhydromonosaccharidic moieties can still be released from the residues even when they have been heated to $310^{\circ} \mathrm{C}$ for $120 \mathrm{~min}[10,13]$. From $T_{\text {oven }}=310^{\circ} \mathrm{C}$ a series of odd numbered masses is becoming more prominent giving the spectrum a different mass peak pattern appearance. These are characteristic for thermally modified polysaccharides, in this case starch $[11,14]$.
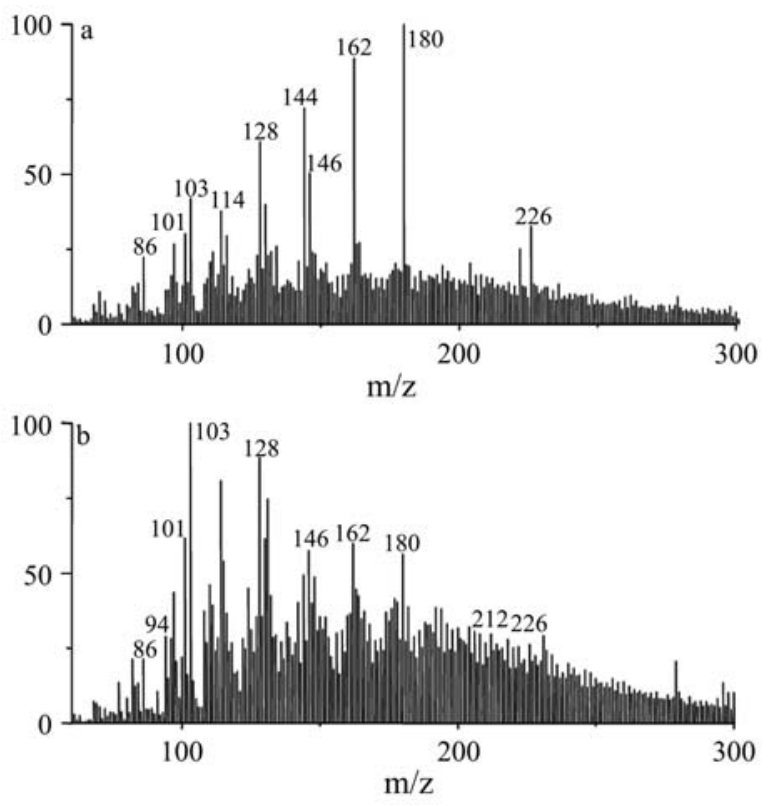

Fig. 4 DTMS(CI) mass spectra of samples of heated grains of emmer wheat (var. AR). Heating time $120 \mathrm{~min}$. $\mathrm{a}-T_{\text {oven }}=270^{\circ} \mathrm{C}$ and $\mathrm{b}-T_{\text {oven }}=310^{\circ} \mathrm{C}$.

Although the protein markers at oven temperatures up to $235^{\circ} \mathrm{C}$ under $\mathrm{CI}$ conditions are not very recognizable it is shown that from $T_{\text {oven }}=250$ up to $370^{\circ} \mathrm{C}$ this method is very useful in determining the presence of proteinaceous material [11]. In the mass spectrum of the sample heated at $250^{\circ} \mathrm{C}$ masses that are characteristic for proteins $(\mathrm{m} / \mathrm{z}$ 84, 86, 101, 103, 146, 212 and 226) are observed (Figs 4a and b) $[11,20,21]$. In order to study the change, as a function of the temperature, of the molecular composition the spectra of the samples of untreated grains and grains heated at $T_{\text {oven }}=130$ up to $370^{\circ} \mathrm{C}$ were analysed by principal component analyses (PCA) over a mass range of $60-400$. The PCA shows that $69 \%$ of the total variance is described by the first principal component. Higher components were ignored. The first component (PC1) describes the conversion of a polysaccharide rich material into an aro- 
matic material as function of the increasing oven temperature. The score plot in Fig. 5 shows negative scores representing the mass peaks characteristic for polysaccharides $\left(\mathrm{PCl}^{-}\right)$. The positive scores represent the heat treated samples at $T_{\text {oven }} \geq 250^{\circ} \mathrm{C}\left(\mathrm{PCl}^{+}\right)$ and show the presence of the protein markers and the pyrolysis products from polysaccharides. From $T_{\text {oven }}=250^{\circ} \mathrm{C}$ the character of the mass spectra starts to change from a number of single polymers into a three-dimensional network polymer at $310^{\circ} \mathrm{C}$. Apparently the proteinaceous material can be considered as relatively thermally stable. The main changes of the molecular composition as a function of the temperature are visualized in Scheme 1.
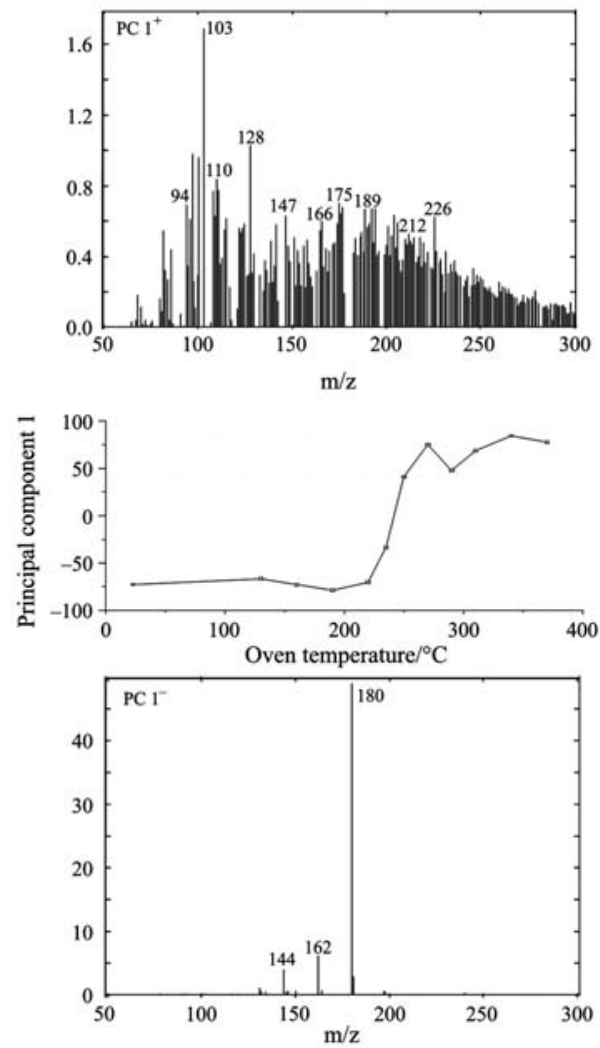

Fig. 5 Score plot of the principal component analysis of DTMS(CI) measurements of untreated and heated grains of emmer wheat (var. $\mathrm{AR}$ ) as a function of the oven temperature in ${ }^{\circ} \mathrm{C}$. Heating time $120 \mathrm{~min} . \mathrm{PCl}^{-}$and $\mathrm{PCl}^{+}$are the 'numerically extracted' mass spectra responsible for the separation into a polysaccharide-rich and an aromatic-rich samples, respectively

\section{DTMS-EI}

DTMS-EI has the potential to reveal more information, in comparison with DTMS-CI, on the proteins and lipids of AR in the lower temperature range and on the 
molecular composition of the residues heated from $250^{\circ} \mathrm{C}$ upwards. Thus, EI experiments were carried out on untreated grains and on the residues heated from $250^{\circ} \mathrm{C}$.

Low voltage EI experiments on untreated biological material show usually protein markers in the range of $m / z 130-200$ [22]. This protein 'hump' is not present in the mass spectrum of the sample of untreated grains of AR. Only mass ions $m / z 69$ (Val, Lys, Arg, Cys); 70, 154 (Arg, Pro, Lys); 84 (Lys, Val, Gln) and 91 (Phe) are observed [23-26] as typical protein markers in the low mass range. Lipids are recognized as fatty acids, sterols, diglycerides and triglycerides. Fatty acids are represented by $m / z 256\left(\mathrm{C}_{16: 0}\right)$ and 262 , $\mathrm{C}_{18: 2}\left(\mathrm{M}-\mathrm{H}_{2} \mathrm{O}\right)$; diglycerides by $m / z 574, \mathrm{C}_{16: 2,18: 2}\left(\mathrm{M}-\mathrm{H}_{2} \mathrm{O}\right)$ and $616, \mathrm{C}_{18: 2,18: 2}$ and triglycerides by $m / z 862\left(\mathrm{C}_{16: 0,18: 0,18: 0}\right)$ and $890\left(\mathrm{C}_{18: 0,18: 0,18: 0}\right)$. Also present are the ions $m / z$ 396-414 of sitosterol $\left(\mathrm{C}_{29: 1}\right)$ and $m / z 430$ of tocopherol.

The mass spectrum of the samples of wheat grains heated from $250^{\circ} \mathrm{C}$ upwards show the mass peaks that describe the conversion of a polysaccharide and protein rich material at $250^{\circ} \mathrm{C}$ into a material that with increasing temperature becomes dominated by aromatic compounds and finally in a strongly $\mathrm{C}$-enriched material [11,27]. These molecular changes, as a function of the temperature, were studied by principal component analyses (PCA), over a mass range from 20-400. The scores of the first (PC1) and the second (PC2) principal component are presented in a score plot (Fig. 6). These
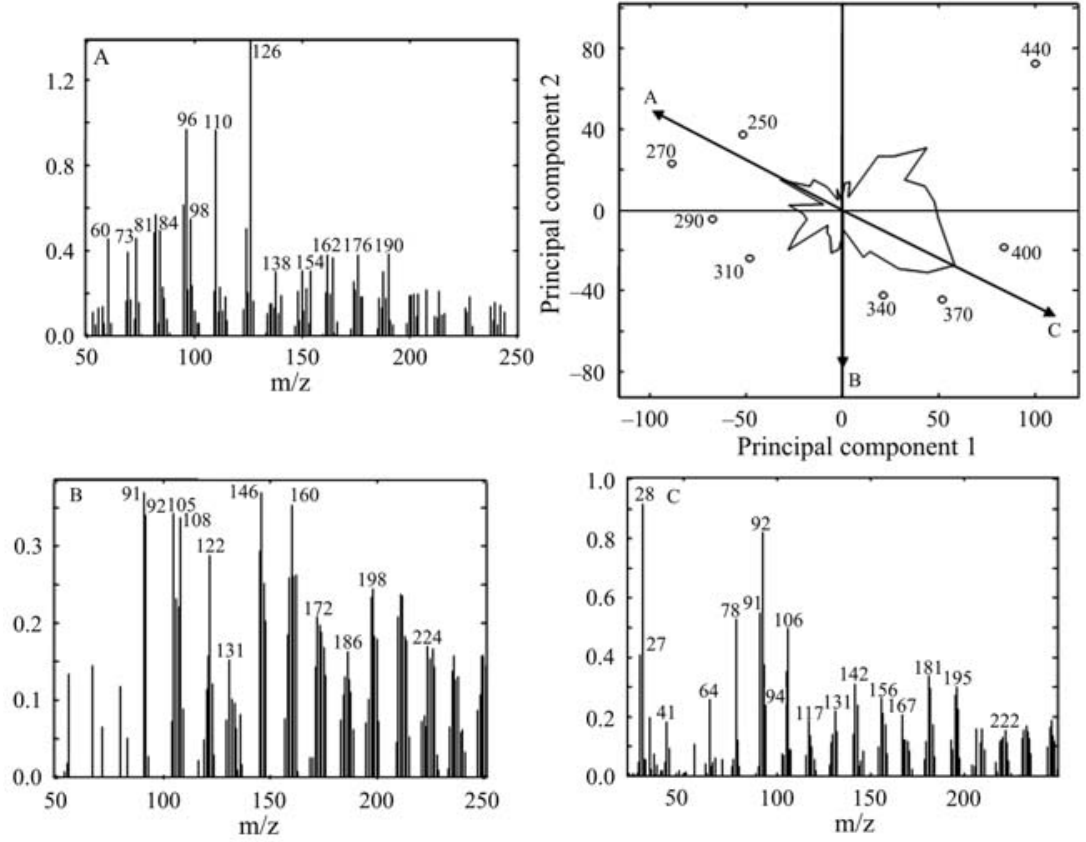

Fig. 6 Score plot of principal components analysis of DTMS(EI) measurements of untreated and heated grains of emmer wheat (var. AR) as a function of the oven temperature. Heating time $120 \mathrm{~min}$. The oven temperatures of the samples are indicated in the figure in ${ }^{\circ} \mathrm{C}$. Product axes $\mathrm{A}, \mathrm{B}$ and $\mathrm{C}$ are superimposed and the 'numerically extracted' mass spectrum of each axis is shown 
components describe, respectively 51 and $27 \%$ of the total variance of $100 \%$. The higher components are ignored. The PCA is used in combination with graphical rotation [12] to adjust the PCA mass spectra to specific thermal regimes. The axes are plotted in Fig. 6, which also show the loading plot. The chemical nature of each axis is visualized by its 'numerically extracted' mass spectrum A, B and C (Fig. 6).

Spectrum A, corresponding to the samples heated at 250 and $270^{\circ} \mathrm{C}$, shows ions indicative of polysaccharides $(\mathrm{m} / \mathrm{z} 60,73,98,126)$, proteins $(\mathrm{m} / \mathrm{z} 70,84,138,154)$ and lipids $(\mathrm{m} / \mathrm{z} 262)$ similarly to the mass spectrum of untreated AR [5]. Ions $m / z 67$ and 81 are tentatively attributed to (alkyl)pyrroles as the result of Maillard or Strecker reactions between sugars and amino acids [28]. The presence of furans is recognized by the release of the ions $m / z 95,96$ and 110 [27]. The series of masses $m / z 148,162,176,190$, etc., which are tentatively attributed to condensed aromatic compounds [29], show the beginning of the conversion of the original biomaterial into an aromatic rich condensed material.

Spectrum $\mathrm{B}\left(\mathrm{DF} 2^{-}\right)$represents a heating temperature, which is just higher than $310^{\circ} \mathrm{C}$. The markers indicative for the presence of polysaccharides, proteins, lipids and furans are no longer present. The spectrum is now characterized by masses released from aromatic compounds. The following functional groups can be recognized: (alkyl)phenols $(\mathrm{m} / \mathrm{z} 108,122)$, (alkyl)benzenes $(\mathrm{m} / \mathrm{z} 91,92,105,106)$ and condensed aromatic compounds $(m / z 146,160,162,172,174,186,198$, etc.) [29]. Two series of odd numbered masses are observed. Firstly by the series $m / z 117,131,145$, etc., identified as (alkyl)indoles derived from Tryptophane in proteins and secondly by the series $m / z 147,161,175$, etc. Both series are attributed to $\mathrm{N}$ containing heterocyclic compounds [30].

Spectrum $\mathrm{C}$ corresponds to a heating temperature of $400^{\circ} \mathrm{C}$. The characteristic ions indicative of condensed aromatic compounds in the sample are no longer present at this temperature. The main ions released from this sample are phenol $(\mathrm{m} / z \mathrm{z} 9)$, (alkyl)benzenes $(\mathrm{m} / \mathrm{z} 78,91,92), \mathrm{SO}_{2}$ from sulfates $(\mathrm{m} / \mathrm{z} 64)$ and the $\mathrm{N}$ containing com-

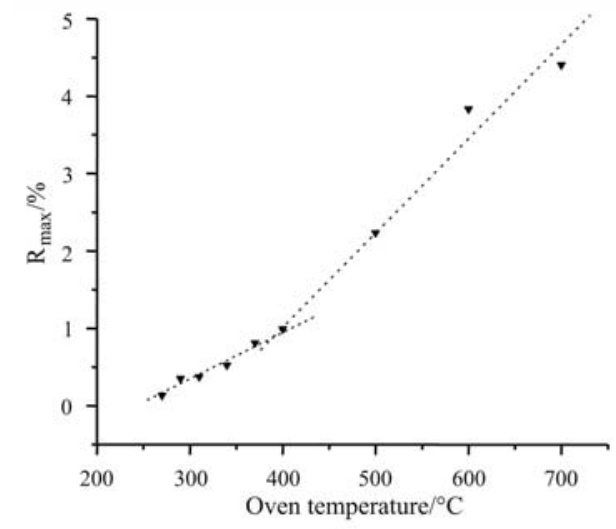

Fig. 7 The results of the vitrinite reflectance $\left(\% R_{\max }\right)$ measurements of heated grains of emmer wheat (var. AR) as a function of the oven temperature in ${ }^{\circ} \mathrm{C}$. Heating time 120 min. $\mathbf{\nabla}$ - emmer wheat 
pounds $\mathrm{HCN}\left(\mathrm{m} / z\right.$ 27) and $\mathrm{CH}_{3} \mathrm{CN}(\mathrm{m} / z$ 41). The series $\mathrm{m} / z$ 167, 181, 195, etc. could point to the formation of alkylidene-imidazole compounds at this temperature [20].

\section{Vitrinite reflectance measurements}

A vitrinite reflectance could be measured on samples from $T_{\text {oven }}=270^{\circ} \mathrm{C}$ upwards. The reflectance of the lowest temperature samples rises slowly from $T_{\text {oven }}=270$ to $400^{\circ} \mathrm{C}$ (Fig. 7). Thereafter the reflectance rises more rapidly. The S.D. of the measurements increases from 0.03 at $T_{\text {oven }}=270^{\circ} \mathrm{C}$ to 0.15 at $600^{\circ} \mathrm{C}$.

\section{Discussion}

Fruits of wheat consist of a fruit coat (pericarp) enclosing the endosperm and the embryo. The endosperm is the bulk material of a grain of wheat and consists for about $60 \%$ of starch and $10-15 \%$ of proteins (Table 1). It has been shown that the presence of the pericarp and the varying content of protein affects the conversion of the untreated grains of wheat upon heat treatment [5]. The changes of the physical properties, the bulk elemental contents and the molecular composition of grains of AR as a function of the oven temperature are summarized in Scheme 1 and will be discussed accordingly. The experimental set-up simulates for example the dropping of wheat grains into an open fire, where the temperature differs as a function of the place where they end up. Thus for each temperature a separate experiment was carried out in a pre-heated oven. The time to reach a constant mass loss decreases as a function of the oven temperature (Fig. 1). Consequently the average heating rate inside the grains increases from a slow $30^{\circ} \mathrm{C} \mathrm{min}^{-1}$ at $T_{\text {oven }}=340^{\circ} \mathrm{C}$ to a moderate $175^{\circ} \mathrm{C} \mathrm{min}^{-1}$ at $700^{\circ} \mathrm{C}$. The oven temperature and the accompanying heating rate of each experiment determines the mechanism and compositional pathway that will occur. The result will be a typical residue for each temperature.

The strong mass loss rate (Fig. 2) in the range of $T_{\text {oven }}=220$ up to $250^{\circ} \mathrm{C}$ is the result of dehydration, which is confirmed by the clear liquid in the outlet tube (Table 2). This liquid was not further analysed, but most likely only water is released at these temperatures and pressures $[14,15]$. The $\mathrm{C}$ content rises strongly from 220 up to $250^{\circ} \mathrm{C}$, indicating that relatively less $\mathrm{C}$ containing compounds were removed from the residues in this temperature range. The molecular composition did not change significantly according to the mass spectra obtained from the samples under DTMS-CI and EI conditions. However the colour of the grains did change from their original colour, through brown into brown-black. This is indicative for the occurrence of Maillard reactions of sugars and amino acids. At $T_{\text {oven }}=250^{\circ} \mathrm{C}$, in spite of the strong dehydration, a material is present that is still characterized by the presence of DTMS features of polysaccharides and proteins. Related to the swollen character of the grains at this temperature it is noted that the starch granules in the endosperm cells did not change in size. The dimensional changes will be discussed elsewhere in a separate study. 
From $T_{\text {oven }}=250$ up to $310^{\circ} \mathrm{C}$ many changes are observed. The polysaccharide rich material changes gradually into a material richer in aromatic compounds. However even the material heated at $310^{\circ} \mathrm{C}$ for $120 \mathrm{~min}$ still contains sugar markers (Fig. 4b). The conversion of polysaccharides into the various aromatic compounds is accompanied by the release of volatiles [31]. Many of these volatiles are apparently not able to pass the pericarp on their way to the external environment and thus a pressure is build up inside the grain resulting in a swelling of the grains and/or collapse of the pericarp between $T_{\text {oven }}=250$ and $270^{\circ} \mathrm{C}$ [11]. Hence, the number of grains with a protrusion increases sharply at $T_{\text {oven }}=270^{\circ} \mathrm{C}$. It needs remarking that the molecular composition of the pericarp, which mostly consists of polysaccharides, has also changed. The sudden release of the volatiles is also expressed in the change of the internal structure as the volatiles apparently are channelled through pipe like structures to the outside. Compounds that were formed as a result of the dehydration, such as anhydrohexoses, decompose further to form furans [27, 32].

Between $T_{\text {oven }}=290$ and $310^{\circ} \mathrm{C}$ the volatile producing endothermic reactions are accompanied by exothermic reactions. The latter being the result of secondary reactions between the converting solids in the reaction zone of the residues and the hot volatiles transferring the residues on their way to the external environment. This suggests that the condensed aromatic compounds at this oven temperature are secondary products, which is also expressed in the increase of the total mass of the residues in comparison to the residue of microcrystalline cellulose (Fig. 2). The volatiles that are released from the residues and condensate in the cold outlet tube are now water and a tarry product, which colours the liquid light to dark yellow (Table 2). At this oven temperature and after heating for 120 min sugar markers are still released from the residues under CI conditions, i.e. mass ions $m / z$ 162, 180, 222 and 240 (Fig. 4b). This agrees with the proposed model as presented by Boon and co-workers [33] regarding the formation of a thermostable polymer network at oven temperatures higher than $\mathrm{c}$. $270^{\circ} \mathrm{C}$ in the residues of heated microcrystalline cellulose, a polysaccharide with a glucose repeating unit almost similar to starch. In their model residual non-volatile glucose cores with attached ring-cleavage fragments, as a result of $(2+2+2)$ cycloreversion reactions, act increasingly from $T_{\text {oven }}=250^{\circ} \mathrm{C}$, as aldolcondensation sites for volatilized compounds that will react with larger non-volatilized residual structural elements. The polymer network has thus changed from a carbohydrate-dominated reactant into a material with mainly aromatic moieties, which are thermally more stable. The performed DTMS-CI experiments provide detailed insights into the conversion of polysaccharides, the bulk material of grains of wheat, as a result of heating.

From $T_{\text {oven }}=310$ up to $400^{\circ} \mathrm{C}$ no major changes in the molecular composition occur. At higher oven temperatures the condensed aromatic compounds are no longer observed. The rate of heating has now strongly increased from a low $30^{\circ} \mathrm{C} \mathrm{min}{ }^{-1}$ at $340^{\circ} \mathrm{C}$ to a moderate $175^{\circ} \mathrm{C}$ at $700^{\circ} \mathrm{C}$. The high reaction rate from $T_{\text {oven }}=440^{\circ} \mathrm{C}$ is causing the release of large quantities of volatiles that appear to be removed from the reaction zone in the grains so fast that no reactions can take place between the volatiles and the converting material inside the grain. Therefore the suggested secondary products such as the condensed aromatic compounds are no longer formed 
from $T_{\text {oven }}=440^{\circ} \mathrm{C}$ upwards. On the other hand the exothermic reaction is still present at these temperatures and other chemical reactions must be the cause for the exotherm [34]. The $\mathrm{C}$ content has increased to $82 \%$ (daf) at $440{ }^{\circ} \mathrm{C}$ and reaches $88 \%$ (daf) at $700^{\circ} \mathrm{C}$. The $\mathrm{N}$ content remains almost constant at c. $5 \%$ (daf), however ions like $\mathrm{m} / \mathrm{z} 27(\mathrm{HCN})$ and $41\left(\mathrm{CH}_{3} \mathrm{CN}\right)$ are still released from the residues under DTMS-EI conditions. Thus a tertiary product is formed characterized by a strong $\mathrm{C}$ enrichment and the presence of $\mathrm{N}$ containing moieties. From $T_{\text {oven }}=400^{\circ} \mathrm{C}$ the maximum vitrinite reflectance $\left(\% R_{\max }\right)$ shows a stronger rise that continues up to $700^{\circ} \mathrm{C}$ (Fig. 6). This rise has been attributed to a progressive ordering of the molecular system that comprises the $\mathrm{C}$ enriched residues of the grains of $\mathrm{AR}[35,36]$.

\section{Implications for the archaeology}

The results of the experiments with recent emmer wheat grains (AR) show that during a120 min exposure up to a temperature of $250^{\circ} \mathrm{C}$, the molecular composition of the residues still consists of dehydrated polysaccharides and of proteins. These residues when deposited into the soil may be microbially degraded similar to the degradation of untreated wheat grains. If the heating takes place between 250 and $310^{\circ} \mathrm{C}$, the residues consist of a decreasing amount of polysaccharides and an increasing amount of aromatic compounds. Whether these residues or parts of it will survive the various degradation processes is not sure. The residues heated at temperatures higher than $310^{\circ} \mathrm{C}$ might have a better chance to survive the degradation processes and thus may be found in the archaeological record. A vitrinite reflectance measurement is a fast and rapid method to determine the temperature at which fruits and seeds, exposed to high temperatures and found in the archaeological record, have been heated. Application of this method will make it possible to verify the earlier statement about the residues heated at temperatures higher than $310^{\circ} \mathrm{C}$.

We thank Miss K. Reimer (Geochemical Research, TNO-NITG, The Netherlands) for her assistance with the vitrinite reflectance measurements. This research is supported by FOM research program 49 funded by the Foundation for Fundamental Research on Matter (FOM), a subsidiary of the Dutch Organisation for Scientific Research (NWO).

\section{References}

1 W. van Zeist, Palaeohistoria, 14 (1970) 41.

2 M. B. Schiffer, American Antiquity, 48 (1983) 675.

3 M. B. Schiffer, Formation Processes of the Archaeological Record (ch. 8), University of New Mexico, Albuquerque 1987.

4 P. Cardillo, J. Therm. Anal. Cal., 72 (2003) 7.

5 F. Braadbaart, C. C. Bakels, J. J. Boon and P. F. van Bergen, Archaeometry, accepted.

6 M. Whitworth, Workshop on Process Engineering of Cereals, Montpellier (2000) 5.

7 F. Mabille, J. C. Benet, J. Abecassis, Y. Haddad and C. Letang, Workshop on Process Engineering of Cereals, Montpellier (2000) 13. 
8 G. C. Hillman, S. Mason, D. de Moulins and M. Nesbitt, Circaea, 12 (1996) 195.

9 International standard, ISO 7404-2 (1985): 'Methods for the petrographic analysis of bituminous coal and anthracite - Part 2: Method of preparing coal samples', ref.no. ISO 7404/2-1985(E).

10 International standard, ISO 7404-5 (1994): 'Methods for the petrographic analysis of bituminous coal and anthracite - Part 5: Method of determining microscopically the reflectance of vitrinite', ref.no. ISO 7404-5: 1994 (E).

11 F. Braadbaart, J. J. Boon, J. van der Horst and P. F. van Bergen, J. Anal. Appl. Pyrol., 71 (2004) 997 in press.

12 W. Windig, J. Haverkamp and P. G. Kistemaker, Anal. Chem., 55 (1983) 81.

13 V. A. Klap, J. J. Boon, M. A. Hemminga and J. van Soelen, Mar. Chem., 54 (1996) 221.

14 I. Pastorova, P. W. Arisz and J. J. Boon, Carbohyd. Res., 248 (1993b) 151.

15 F. Braadbaart, J. J. Boon, H. Veld, P. David and P. F. van Bergen, J. Arch. Sci., 31 (2004) 821.

16 N. Ravi Jr. and M. Jerry Antal, Ind. Eng. Chem. Res., 35 (1996) 1711.

17 D. Bradbury, I. M. Cull and M. M. MacMasters, Cereal Chem., 33 (1956) 329.

18 T. Evers and S. Millar, J. Cereal Sci., 36 (2002) 261.

19 H.-D. Belitz and W. Grosch, Food Chemistry, $2^{\text {nd }}$ ed., Springer, Berlin 1999.

20 J. de Waart, A. C. Tas, G. F. La Vos and J. van der Greef, J. Anal. Appl. Pyrol., 24 (1992) 245.

21 A. C. Tas, unpublished work.

22 J. C. M. van de Arendonk, G. J. Niemann and J. J. Boon, J. Anal. Appl. Pyrol., 42 (1997) 33.

23 M. Scheijen, Analytical pyrolysis studies on tobacco, Amsterdam 1991.

24 G. Chiavari and G. C. Galletti, J. Anal. Appl. Pyrol., 24 (1992) 123.

25 B. A. Stankiewicz, P. F. van Bergen, I. J. Duncan, J. F. Carter, E. G. Briggs and R. P. Evershed, Rapid Communications in Mass Spectrometry, 10 (1996) 1747.

26 J. J. Boon and J. W. de Leeuw, J. Anal. Appl. Pyrol., 11 (1987) 313.

27 I. Pastorova, R. E. Botto, P. A. Arisz and J. J. Boon, Carbohydrate Res., 262 (1994) 27.

28 G. Vernin and C. Párkányi, in: G. Vernin, The chemistry of heterocyclic flavouring and aroma compounds, Ellis Horwood Ltd., 1982.

29 I. Pastorova, T. F. M. Oudemans and J. J. Boon, J. Anal. Appl. Pyrol., 25 (1993a) 63.

30 S. C. Moldoveanu, Analytical Pyrolysis of Natural Organic Polymers, Elsevier, Amsterdam 1998. 31 F. Shafizadeh, Appl. Polym. Symp., 28 (1975) 153.

32 U. Räisänen, I. Pitkänen, H. Haittunen and M. Hurtta, J. Therm. Anal. Cal., 72 (2003) 481.

33 J. J. Boon, I. Pastorova, R. E. Botto and P. W. Arisz, Biomass and Bioenergy, 7 (1994) 25.

34 G. Várhegyi and E. Jakab, Energy and Fuels, 8 (1994) 1345.

35 F. Goodarzi and D. G. Murchison, Fuel, 51 (1972) 322.

36 D. G. Murchison, in: C. Karr Jr., Analytical Methods for Coal and Coal Products, Academic Press, New York 1978. 